\title{
AKCIA REINHARDT A DEPORTÁCIE SLOVENSKÝCH ŽIDOV DO LUBLINSKEJ OBLASTI V DOKUMENTOCH
}

\author{
JÁN H L A V I N K A - MICHAL S C H VA R C
}

HLAVINKA, Ján - SCHVARC, Michal. Operation Reinhardt and the Deportation of Slovak Jews to the Lublin District Through Documents. Historický časopis, 2021, 69, 4, pp. 729-754, Bratislava.

In 1942, the regime of Hlinka's Slovak People's Party deported more than 57,000 Jews to territory under the control of the Third Reich. Of these, 40,000 Jews were deported to the General Government's Lublin District, where Operation Reinhardt, one of the biggest extermination operations of the Holocaust, was just beginning. Its central elements were Belzec, Sobibor and Treblinka death camps. Therefore, the vast majority of Jews deported from Slovakia in 1942 fell victim to extermination Operation Reinhardt. The article presents a set of documents that characterize deportations of Slovak Jews to the Lublin District, as well as Operation Reinhardt itself.

Keywords: Holocaust. Deportations. Operation Reinhardt. Slovak state. Jews. Death camps.

DOI: https://doi.org/10.31577/histcaso.2021.69.4.7

Problematika prvej vlny deportácií Židov zo Slovenska, ktorá sa začala 25. marca 1942 a trvala do 20. októbra toho istého roka, patrí medzi pomerne dobre spracované kapitoly dejín holokaustu pokial' ide o organizáciu celej akcie a jej priebeh na území Slovenska.

Osudy jednotlivých transportov a obetí po tom, čo v niektorej z nákladných vlakových súprav prekročili štátnu hranicu medzi Slovenskom a Generalgouvernementom, však za dostatočne spracované označit' nemôžeme. Aj ked' sa výskum najmä v posledných rokoch výrazne posunul a historikom pôsobiacim v Pol'sku, Izraeli, USA a v poslednej dobe aj na Slovensku sa podarilo naše poznanie výrazne prehíbit', spracovanie osudov deportovaných na mieste určenia transportov je stále nedostatočné, a to najmä v prípade obetí deportovaných do Lublinskej oblasti.

Transporty zo Slovenska smerovali do Lublinskej oblasti od 27. marca 1942 do 14. júna $1942 .{ }^{1}$ Do tejto administratívno-správnej časti Generalgouvernemen-

1 KIEŁBOŃ, Janina. Deportacje Żydów do dystryktu lubelskiego (1939-1943). In LIBIONKA, Dariusz (ed.). Akcja Reinhardt. Zagłada Żydów w Generalnym Gubernatorstwie. War- 
tu vypravili zo Slovenska 38 z celkovo 57 transportov, teda väčšinu transportov z prvej vlny deportácí́ a celkovo v nich bolo deportovaných 39899 osôb. ${ }^{2}$

Súbor dokumentov, ktoré publikujeme $\mathrm{v}$ tomto príspevku nevyčerpáva ani zd’aleka všetky otázky, ktoré je potrebné ešte zodpovedat' vo vzt’ahu k uvedeným transportom. Naopak, je len jednou zo sond do celého problému, akýmsi súborom dokumentov, ktoré ukazujú niektoré kl'účové fázy a typické momenty deportácií slovenských Židov do Lublinskej oblasti.

O úvodnom pláne deportovat' asi 10000 Židov do Lublinskej oblasti boli miestne nemecké okupačné orgány informované 24 . marca 1942, teda deň pred začiatkom celej deportačnej akcie na Slovensku. K realizácii plánu prišlo už o niekol'ko dní. Prvý transport slovenských Židov, ktorý dorazil do Lublinskej oblasti bol v poradí druhým transportom Židov zo Slovenska. Boli v ňom výlučne muži vo veku 16 - 45 rokov a vypravili ho zo Žiliny 27 . marca $1942 .{ }^{3}$ Išlo o úvodnú fázu deportácií Židov, počas ktorej boli v každom z transportov zo Slovenska vyvážané osoby rovnakého pohlavia, označené za tzv. práceschopné.

Prví slovenskí Židia, ktorí teda prichádzali na prelome marca a apríla 1942 do Lublinskej oblasti boli výlučne muži, pričom ženy boli v tomto období zo Slovenska deportované do koncentračného a vyhladzovacieho tábora Auschwitz. ${ }^{4}$

Tu je dôležité povedat', že iba niekol'ko dní pred príchodom prvých Židov deportovaných zo Slovenska, presnejšie 16. marca 1942, sa v Lubline začala akcia, ktorej ciel’om bola fyzická likvidácia všetkých Židov žijúcich či privážaných na územie Generalgouvernementu a zaistenie ich majetku. Hlavní organizátori uvedenej akcie, sídliaci v jej lublinskom štábe ju neskôr nazvali „akcia Reinhardt“ (Einsatz Reinhardt). ${ }^{5}$ Jej kl'účovým elementom boli postupne dobudovávané a do prevádzky spúšt’ané vyhladzovacie tábory Belzec, Sobibor a Treblinka. Tieto tábory boli úmyselne situované do odl'ahlých, riedko osídlených zalesnených

szawa: Instytut Pamięci Narodowej, 2004, s. 173 - 174. ISBN 8389078686.

2 NIŽŇANSKÝ, Eduard (ed.). Holokaust na Slovensku 6. Deportácie v roku 1942. Dokumenty. Bratislava: Nadácia Milana Šimečku, 2005, s. 487 - 488. ISBN 8096924230; GRUDZIŃSKA, Marta. Żydzi slowaccy v obozie koncentracyjnym na Majdanku. In Studia Żydowskie Almanach, 2014, roč. IV, č. 4, s. 55. ISSN 2083-5574.

3 Pozri Dokumenty č. 1 a 2.

4 K prvým transportom žien zo Slovenska do tábora Auschwitz pozri STRZELECKA, Irena. The First Transports of Women to Auschwitz. In The Tragedy of the Jews of Slovakia 19381945: Slovakia and the „Final Solution of the Jewish Question“. Oświecim: Auschwitz-Birkenau State Museum; Banská Bystrica: Museum of the Slovak National Uprising, 2002, s. 186. ISBN 8388526154.

5 SILBERKLANG, David. Gates of Tears. Jerusalem: Yad Vashem, 2014, s. 281 - 282. ISBN 9789653084643; LIBIONKA, Dariusz. Zagłada Żydów v Generalnym gubernatorstwie. Zarys problematyki. Lublin: Państwowe Muzeum na Majdanku, 2017, s. 107 - 112. ISBN 9789653084643. 
lokalít s dobrým železničným spojením, čo malo zabezpečit' utajenie celej akcie a zároveň aj jej bezproblémový priebeh z hl'adiska logistiky. Tábory boli totiž zriadené za účelom fyzickej likvidácie tisícok obetí v priebehu niekol'kých hodín od ich dovezenia na rampu tábora. Na tento účel slúžili táborové plynové komory, v ktorých sa ako vraždiaci prostriedok nepoužíval Zyklon B, ale spaliny spal'ovacích motorov (obsahujúce oxid uhol'natý).

V neskoršej fáze akcie Reinhardt, na jeseň 1942, boli k plynovým komorám $\mathrm{v}$ troch vyššie menovaných vyhladzovacích táboroch doplnené d’alšie plynové komory v koncentračnom tábore Lublin (Majdanek), hoci tento tábor dovtedy a aj v nasledujúcom období slúžil najmä ako koncentračný a poskytoval otrockú pracovnú silu pre triedenie hnutel'ného majetku zavraždených obetí či budovanie infraštruktúry. ${ }^{6}$

Transporty zo Slovenska začali prúdit' do Lublinskej oblasti v momente, ked' sa štáb akcie Reinhardt zaoberal jej prvou fázou, zameranou na fyzickú likvidáciu miestneho židovského obyvatel'stva v prvom dokončenom vyhladzovacom tábore - Belzec. ${ }^{7}$ Zakrátko po príchode prvých slovenských transportov, v apríli 1942, bol spustený aj druhý vyhladzovací tábor, nazývaný nacistami , SS-Sonderkommando Sobibor".8.

Všetky úvodné transporty tzv. práceschopných slovenských židovských mužov (vo veku 16 - 45 rokov) smerovali nemeckí organizátori akcie Reinhardt priamo do koncentračného tábora Majdanek, kde práve prebiehala výstavba tábora. Reč je o transportoch, ktoré odišli zo Slovenska medzi 27. marcom 1942 a 5. aprílom 1942. ${ }^{9} \mathrm{O}$ podmienkach, aké panovali v transportoch počas deportácie a neskôr počas presunu do tábora Majdanek, ako aj o tom, v akých podmienkach v tomto tábore museli žit' a umierat' židovskí väzni zo Slovenska, vypovedá jeden z predložených dokumentov, ${ }^{10}$ ale aj unikátne svedectvo jedného $\mathrm{z}$ utečencov z Lubinskej oblasti Dionýza Lénarda, ktoré bolo publikované v niekol'kých jazykoch a v roku 2015 sa dočkalo aj slovenského vydania. ${ }^{11}$

6 KRANZ, Tomasz. Extermination of Jews at the Majdanek Concentration Camp. Lublin: Państwowe Muzeum na Majdanku, 2007, s. 3. ISBN 9788392518709.

7 Bližšie pozri KUWAŁEK, Robert. Obóz zagłady w Bełżcu. Lublin: Państwowe Muzeum na Majdanku, 2010. ISBN 9788392518785.

8 OLEKSY-ZBOROWSKI, Tomasz. Vyhladzovací tábor Sobibor. In HLAVINKA, Ján - SALNER, Peter (eds.). Tábor smrti Sobibor: Dejiny a odkaz. Bratislava: Marenčin PT, s. 40, 44. ISBN 9788056904497.

9 GRUDZIŃSKA, ref. 2, s. 63.

10 Pozri dokument č. 10.

11 HLAVINKA, Ján. „Dôjst' silou-mocou na Slovensko a informovat'.. “ : Dionýz Lénard a jeho útek z koncentračného tábora Majdanek. Bratislava: Historický ústav SAV vo Vydavatel'stve Veda, 2015, s. 57 - 123. ISBN 9788022414814. 
Ďalšia fáza prvej vlny deportácí Židov zo Slovenska sa začala transportom, ktorý odišiel z Trnavy 11. apríla 1942 a ktorý bol prvým tzv. rodinným transportom Židov. Od 11. apríla boli v takýchto transportoch spoločne deportované osoby oboch pohlaví bez ohl'adu na vek. Transport z Trnavy smeroval do Lublinskej oblasti, pričom príslušníci SS zo štábu akcie Reinhardt naň aplikovali iný metodický postup, ktorý neskôr viackrát zopakovali pri nasledujúcich transportoch zo Slovenska. Spočíval v tom, že po zastavení transportu v Lubline (v lublinskom pracovnom tábore Alter Flughafen, nazývanom aj „Flugplatz"), vybrali z transportu čast' mužov a odviedli ich do koncentračného tábora Majdanek. Nevyselektované osoby následne pokračovali v transporte do niektorého $\mathrm{z}$ tzv. prechodných get $\mathrm{v}$ Lublinskej oblasti. ${ }^{12}$

Konečná stanica tzv. rodinných transportov zo Slovenska pritom nebola vždy konečnou lokalitou, v ktorej boli deportované osoby uväznené a po úvodnom rozdelení v Lubline ešte mnohokrát dochádzalo $\mathrm{k}$ d’alším dislokáciám osôb po rôznych prechodných getách, resp. blízkych mestečkách a obciach. ${ }^{13}$

Slovenskí Židia boli posielaní do lokalít, v ktorých pred ich príchodom došlo k selekciám, vraždeniu a deportáciám miestneho židovského obyvatel'stva, ako aj Židov dovezených z iných častí strednej Európy. Často ich teda nastahovali do obydlí, ktorých pôvodní majitelia a aj dočasní obyvatelia z predchádzajúcich transportov, už boli medzitým povraždení vo vyhladzovacích táboroch. ${ }^{14}$

Z niekol'kých málo svedectiev preživších (z ktorých čast' tvoria židovskí utečenci zo Slovenska a čast' pol'skí Židia) je jasné, že podmienky v týchto lokalitách (prechodné getá) boli katastrofálne a že slovenskí Židia sa ocitali v neznámom prostredí, nacistami roky terorizovaných a práve fyzicky likvidovaných židovských komunít, $\mathrm{v}$ rámci ktorých za splnenie tvrdých nariadení a požiadaviek nemeckých úradných miest a represívnych orgánov zodpovedali životom tzv. Židovské rady (Judenrat-y) a poriadkové služby (Ordnungsdienst-y, skratka: OD). Zápasili pritom s totálnym nedostatkom potravín či základných potrieb pre väznené židovské obyvatel'stvo.

Prechodné getá plnili v rámci akcie Reinhardt funkciu dočasných miest dislokácie obetí pred ich konečnou fyzickou likvidáciou a zo strany príslušníkov SS, ako aj úradných miest im bola venovaná minimálna pozornost'. Obete sa ocitali, ako sme už naznačili, v otrasných hygienických a ubytovacích podmienkach,

12 Pozri dokumenty č. 4 a 5; Pozri tiež GRUDZIŃSKA, ref. 2, s. 63 - 64; KUWAŁEK, Robert. Getta tranzytowe w dystrykcie lubelskim. In Akcja Reinhardt. Zagłada Żydów w Generalnym Gubernatorstwie. Warszawa: Instytut Pamięci Narodowej, 2004, s. 138. ISBN 8389078686.

13 Pozri dokumenty č. 5 a 6.

14 Pozri dokumenty č. 8, 9; Pozri tiež SILBERKLANG, ref. 5; MUSIAŁ, Bogdan. „Przypadek modelowy dotyczący eksterminacji Żydów“. Poczatki „akcji Reinhardt“- planowanie masowego mordu Żydów v Generalnym Gubernatorstwie. In Akcja Reinhardt, ref. 12, s. $15-38$. 
natlačené v malých príbytkoch, ktoré zostali po vyvraždenom miestnom židovskom obyvatel'stve, kde často vznikali epidémie nákazlivých chorôb zapríčiňujúce značnú úmrtnost'. Boli tiež nútené t’ažko pracovat' a to s minimálnym prídelom potravín, čo ich samo osebe fyzicky vysil'ovalo. ${ }^{15}$

Po niekol'kých týždňoch až mesiacoch od deportácie pritom organizoval štáb akcie Reinhardt $\mathrm{v}$ jednotlivých getách deportačné akcie, počas ktorých nacisti prevážali obete do niektorého $\mathrm{z}$ vyhladzovacích táborov a tam ich vraždili. V prípade slovenských Židov išlo predovšetkým o tábor Sobibor. ${ }^{16}$

Počas týchto likvidačných akcií boli spravidla priamo na mieste, teda $\mathrm{v}$ gete a v jeho okolí strel'bou povraždené tie osoby, ktoré nemohli byt' deportované pre zlý fyzický stav (spôsobený chorobou či vysilením). Strel'ba do zhromažd’ovaných Židov tiež slúžila nacistom na šokovanie deportovaných Židov a vynútenie si ich poslušnosti.

Na miesto po deportovaných a povraždených Židoch boli následne privezené d’alšie osoby z nových transportov. Tento metodický postup nacisti nazývali „výmena Židov“" alebo aj „metóda otočných dverí“. ${ }^{17}$

Od 1. júna 1942 už transporty zo Slovenska nerozmiestňovali po getách a rôznych lokalitách v Lublinskej oblasti, ale nasmerovávali ich priamo do vyhladzovacieho tábora Sobibor. Pri všetkých transportoch urobili príslušníci SS počas ich zastavenia $v$ Lubline selekciu. ${ }^{18}$

Na základe toho sa osudy vel'kej časti z takmer 40-tisíc slovenských Židov deportovaných zo Slovenska do Lublinskej oblasti v roku 1942 spájajú s celým radom lokalít na území dnešného východného Pol'ska, no najmä s lokalitami niekdajších nacistických vyhladzovacích táborov. Najviac obetí zo Slovenska zahynulo práve vo vyhladzovacom tábore Sobibor. ${ }^{19}$

Medzi publikovanými dokumentmi sa nachádza aj unikátne svedectvo Jozefa Schnitzera, pôvodom zo Sabinova, ktorý bol deportovaný do jedného z get Lublinskej oblasti (geto Rejowiec), prežil likvidačnú akciu v tomto gete a deportáciu do vyhladzovacieho tábora Sobibor, selekciu na rampe tohto tábora a aj následný presun do pracovného tábora Krychów, odkial' neskôr ušiel a vrátil sa na Slovensko.

Toto svedectvo vzniklo v roku 1943 a v minulosti už bolo historikmi publikované ako Správa zo Slovenska deportovaného a vrátivšieho sa Žida v nemeckom jazyku, prípadne fragmentárne v rôznych zahraničných publikáciách. K stotož-

15 Pozri dokument č. 8.

16 HLAVINKA, Ján. Deportácie Židov zo Slovenska do tábora smrti Sobibor. In HLAVINKA SALNER, ref. 8, s. 136.

17 SILBERKLANG, ref. 5, s. 299.

18 GRUDZIŃSKA, ref. 2, s. 64.

19 HLAVINKA, ref. 16, s. 136. 
neniu autora svedectva došlo až v roku $2018,{ }^{20}$ pričom plná slovenská verzia svedectva, ktorá sa nachádza $\mathrm{v}$ archíve pamätníka Jad Vašem v Jeruzaleme, je publikovaná po prvýkrát práve $\mathrm{v}$ tomto príspevku.

Archeografická poznámka:

Dokumenty nemeckej proveniencie editori preložili do slovenčiny, pričom slovenský preklad je vždy uvedený pod originálnym nemeckým znením dokumentu.

$\mathrm{V}$ dokumentoch $\mathrm{v}$ slovenskom jazyku editori pristúpili $\mathrm{k}$ ich jazykovej úprave a zosúladili ich so súčasnou slovenskou gramatikou (písanie grafém i/y; s/z; doplnenie a korektúra interpunkcie).

* Štúdia vznikla v rámci projektu VEGA č. 2/0134/20 Akcia Reinhardt a Slovensko. Osudy slovenských Židov deportovaných v roku 1942 do Oblasti Lublin.

20 HLAVINKA, ref. 16, s. $131-132$. 


\title{
Dokument 1
}

\section{Ďalekopis Hospodárskeho a správneho úradu SS velitel’ovi tábora pre vojnových zajatcov v Lubline z 24. marca 1942 o príchode deportovaných Židov zo Slovenska}

\author{
Abschrift
}

Oranienburg FS Nr. 903 24. 3. 194212.59

An den SS-Standartenführer Koch

Kommandant des KGL Lublin

Betr. Juden aus der Slowakei

Die für das dortige Lager bestimmten 10000 (Zehntausend) Juden aus der Slowakei werden ab 27. 3. 1942, wie bereits mitgeteilt, mit Sonderzügen nach dort überstellt werden. Jeder Sonderzug führt 1000 (eintausend) Häftlinge mit. Alle Züge werden über den Grenzbahnhof Zwardon $\left(\mathrm{OS}^{21}\right)$ geleitet, wo sie jeweils 6.09 Uhr früh eintreffen und während eines zweistündigen Aufenthaltes von Begleitkommandos der Schutzpolizei unter Aufsicht der Staatspolizeistelle Kattowitz an den Bestimmungsort weitergeleitet werden. Die Führer der Begleitkommandos führen namentliche Transportlisten mit. Mit der Reichsbahn wurden zunächst für die ersten 4 Transporte folgende Fahrpläne vereinbart. DA $^{22} 67$ am 27. 3., DA 69 am 30. 3., DA 70 am 31. 3., DA 72 am 5. 4. ${ }^{23}$ An diesen Tagen Ankunft in Zwardon 6.09 Uhr, Abfahrt ab Zwardon 8.20 Uhr, Ankunft in Lublin um 6.30 Uhr des darauffolgenden Tages. Die Fahrpläne für die weiteren 6 Transporte werden nachträglich noch mitgeteilt.

Wie bereits mit dem FS Nr. 886 vom 23. 3. $1942^{24}$ befohlen, ist das Eintreffen und die Übernahme der einzelnen Transporte zahlenmässig unter Angabe der mitgebrachten Verpflegung sofort durch FS hierher zu melden.

\author{
D. Ch. d. Zentralamtes \\ gez. Liebeshenschel \\ SS-Obersturmbannführer
}

\section{Odpis}

Oranienburg d’alekopis č. 903 24. 3. 194212.59

SS-Standartenführerovi Kochovi

velitel'ovi tábora pre vojnových zajatcov Lublin

21 Oberschlesien - Horné Sliezsko.

22 Akcia David - krycie meno pre deportovanie Židov z Nemeckej ríše, Protektorátu Čechy a Morava a Slovenska.

23 Porovnaj NIŽŇANSKÝ, Eduard (ed.). Holokaust na Slovensku 4. Dokumenty nemeckej proveniencie (1939 - 1945). Bratislava: Nadácia Milana Šimečku, 2003, dokument 32, s. 116 - 117. ISBN 8096866230.

24 Dokument nemáme k dispozícii. 
Vec Židia zo Slovenska

10000 (desat'tisíc) Židov zo Slovenska určených pre tamojší tábor, budú od 27. 3. 1942, ako už bolo oznámené, prepravovaní do Lublina osobitnými vlakmi. Každý osobitný vlak privezie 1000 (tisíc) zajatcov. Všetky vlaky pôjdu cez pohraničnú železničnú stanicu Zwardoň (Horné Sliezko), kam dorazia zakaždým ráno o 6.09 hodine a počas dvojhodinovej zastávky ich pod kontrolu úradovne Štátnej polície Katovice prevezmú sprievodné oddiely Ochrannej polície. Velitelia sprievodných oddielov dostanú deportačné zoznamy. S Ríšskymi železnicami sa dohodli prvé štyri transporty podl'a nasledovného cestovného poriadku:

DA 67 27. 3., DA 69 30. 3., DA 70 31. 3., DA 72 5. 4. V týchto dňoch príchod do Zwardone 6.09, odchod zo Zwardone 8.20, príchod do Lublinu o 6.30 nasledujúceho dňa. Cestovné poriadky pre d'alších šest' transportov budú oznámené dodatočne.

Podl'a rozkazu z d'alekopisu č. 886 z 23. 3. 1942, treba príchod a prevzatie jednotlivých transportov s počtom a s uvedením privezeného proviantu okamžite sem nahlásit' d'alekopisom.

Š́f ústredného úradu pod. Liebeshenschel

SS-Obersturmbannführer

BArch Ludwigsburg, B 162/1843, Bl. 8. Odpis, strojopis, 1 strana.

\section{Dokument 2 \\ Prípis riaditel'stva Ríšskych železníc vo Viedni pre slovenské ministerstvo dopravy a verejných prác vo veci cestovných nákladov za deportačné transporty z 25 . marca 1942}

Deutsche Reichsbahn

Reichsbahndirektion Wien Wien, den 25. März 1942

9 Vtp 3 Tpa

An das

Verkehrsministerium, Eisenbahndirektion II, Abt. 4 in Bratislava, nachr. RDB ${ }^{25}$ Oppeln, Gedob ${ }^{26}$ Krakau und $\mathrm{VK}^{27}$ I Wien

Betrifft: Da-Züge Slowakei - Deutschland und Slowakei - General Gouvernement

25 Reichsbahndirektion.

26 Generaldirektion der Ostbahn.

27 Verkehrskontrolle. 
Über Ihr fernmündliches Ersuchen geben wir Ihnen folgende Fahrpreise für DaSonderzüge bekannt:

Zwardon/Skalite - Auschwitz

km 91 Einzelfahrpreis 3. Kl. RM 3,70

Zwardon/Skalite - Dulowa/Trzebinia

Dulowa/Trzebinia - Lublin

Kinder von 4 - 10 Jahren zahlen die Hälfte. Es wird der Fahrpreis für mindestens 400 ganze Fahrkarten 3. Klasse und im ganzen mindestens $400 \mathrm{RM}$ je gesondert für deutsche und Ostbahnstrecken erhoben. Keine Freikarten.

Abfertigung auf Beförderungsschein des deutsch-slowakischen Verkehrs durchgehend bis zum Zielbahnhof des Sonderzuges.

\section{Reichsbahndirektion Wien}

Nemecké ríšske železnice

Riaditel'stvo ríšskych železníc Viedeň

Viedeň, 25. marca 1942

9 Vtp 3 Tpa

Ministerstvu dopravy, riaditel'stvo železníc II, odd. 4 v Bratislave, pre informáciu RDB Opole, Gedob Krakov a VK I Viedeň

Vec: Vlaky Da Slovensko - Nemecko a Slovensko - Generálny gouvernement

Na Vaše telefonické dožiadanie Vám oznamujeme nasledovné cestovné pre osobitné vlaky Da:

Zwardoň/Skalité - Auschwitz

km 91 jednotkové cestovné 3. tr. RM 3,70

Zwardoň/Skalité - Dulowa/Trzebinia

$\mathrm{km} 122$ jednotkové cestovné 3. tr. RM 4,90

Dulowa/Trzebinia - Lublin

$\mathrm{km} 352$ jednotkové cestovné 3. tr. RM 12,35

Deti od 4 do 10 rokov platia polovicu. Účtuje sa cena za cestovné za minimálne 400 celých lístkov 3. triedy a celkovo minimálne 400 RM zvlášt' pre nemecké a východné trate. Žiadne bezplatné cestovné lístky.

Vypravovanie bude priebežne prebiehat' až do ciel'ovej stanice osobitného vlaku na základe prepravného listu nemecko-slovenského dopravného styku.

Riaditel'stvo ríšskych železníc Viedeň

ROTHKIRCHEN, Livia. The destruction of Slovak Jewry. Jerusalem: Yad Vashem, 1961, dokument 30 .

\section{Dokument 3 \\ Ďalekopis úradovne Štátnej polície v Katoviciach o prijatí 2. transportu Židov zo Slovenska na pohraničnej stanici v Zwardoni z 27. marca 1942}


Stl. ${ }^{28}$ Kattowitz 4643 27. 3. 429.30

An das RSHA IV B 4 Berlin ${ }^{29}$

an das Wirtschafts- und Verwaltungsamt - Amtsgruppe D

Konzentrationslager in Oranienburg

an den Befehlshaber der Sipo u. d. $\mathrm{SD}^{30}$ in Krakau

an das KL Lublin

\section{Geheim - Dringend - sofort vorlegen}

Betr:: Arbeitseinsatz von 20000 Juden aus der Slowakei

Vorg.: FS-Erlass des RSHA Berlin IV B 4 a-2142/42 g (1090)

Ankunft des 2. Zuges in Zwardon mit 1000 arbeitsfähigen Juden aus der Slowakei am 27. 3. 42 um 6 Uhr 52 Min. Abfahrt um 8 Uhr 5 Min. von Zwardon nach KL Lublin. Bei dem Transport befand sich ein jüd. Arzt, sodass Gesamtzahl 1001 Mann ist. Der Transport wurde ordnungsmässig übernommen und an die Begleitmannschaft in Stärke von 20 Beamten der Ordnungspolizei unter Führung Res. Ltn. Schwiendek von der II. Komp. Res. Pol. Btl. ${ }^{31} 83 \mathrm{Krenau}^{32}$ übergeben.

Mitgeführte Verpflegung: $210 \mathrm{~kg}$ Kunstfett, $210 \mathrm{~kg}$ Kochmehl, $50 \mathrm{~kg}$ Zwiebel, $140 \mathrm{~kg}$ Salz, 6 kg Paprika, 1 kg Pfeffer, 100 kg Bohnen, 100 kg Erbsen, 600 Kg Kartoffeln, 800 kg Sauerkraut, 200 kg Wurst, 240 kg Brotmehl, 400 kg Brot, 1131 Essig, 7000 kg Holz.

Stl. Kattowitz IV B 4 18/72

i. V. gez. Woltersdorf

Hlavná úradovňa Štátnej polície Katovice 4643 27. 3. 429.30

RSHA IV B 4 v Berlíne

Hospodárskemu a správnemu úradu - úradná skupina D

koncentračný tábor v Oranienburgu

náčelníkovi Sipo a SD v Krakove

koncentračnému táboru Lublin

Tajné - naliehavé - okamžite predložit'

Vec: Pracovné nasadenie 20000 Židov zo Slovenska

28 Staatspolizeileitstelle.

29 Eichmannov referát pre záležitosti židovského obyvatel'stva v Nemecku, v okupovanej Európe a v spojeneckých štátoch $\mathrm{v}$ Hlavnom úrade pre ríšsku bezpečnost' (Reichssicherheitshauptamt).

30 Sicherheitspolizei a Sicherheitsdienst.

31 Reserve-Polizeibataillon - záložný policajný prápor.

32 Chrzanów, mesto v dnešnom Malopol'skom vojvodstve. 
Predošlý spis.: Ďalekopisné nariadenie RSHA Berlín IV B 4 a-2142/42 g (1090)

Príchod 2. vlaku s 1000 práceschopnými Židmi zo Slovenska do Zwardone 27. 3. 42 o 6.52 hod. Odchod zo Zwardone do KT Lublin o 8.05 hod. V transporte sa nachádzal aj jeden židovský lekár, takže celkový počet je 1001 mužov. Transport bol riadne prevzatý a zverený sprievodnému mužstvu pod velením poručíka v zálohe Schwiendeka z II. roty záložného policajného práporu 83 v Krenau.

So sebou vezený proviant: $210 \mathrm{~kg}$ umelého tuku, $210 \mathrm{~kg}$ múky na varenie, $50 \mathrm{~kg}$ cibule, $140 \mathrm{~kg}$ soli, $6 \mathrm{~kg}$ papriky, $1 \mathrm{~kg}$ korenia, $100 \mathrm{~kg}$ fazule, $100 \mathrm{~kg}$ hrachu, $600 \mathrm{~kg}$ zemiakov, 800 kg kyslej kapusty, 200 kg salámy, 240 kg chlebovej múky, 400 kg chleba, 1131 octu, $7000 \mathrm{~kg}$ dreva.

Stl. Katovice IV B 4 18/72

v z. pod. Woltersdorf

BArch Ludwigsburg, B 162/1843, Bl. 23. Odpis, strojopis, 1 strana.

\section{Dokument 4 \\ Prípis žandárskeho stanovišt’a v Lubartówe žandárskej stanici v Lubline vo veci príchodu transportu zo Slovenska do Lubartówa zo 14. apríla 1942}

Gend.-Posten Lubartow

Kreis Lublin,

Distrikt Lublin

Tgb. Nr. 614/42

Lubartow, den 14. April 1942

An

den Gendarmeriezug

in Lublin

Betrifft: Umsiedlung von Juden.

Am 9. 4. 1942 wurden aus Lubartow mit der Eisenbahn 650 Juden mit hier nicht bekanntem Ziel umgesiedelt. An deren Stelle trafen nun am Nachmittag des 13. 4. 1942 ungefähr 900 aus Preßburg i. d. Tschechoslowakei kommende Juden in Lubartow ein. ${ }^{33}$ Wegen Quartiermangel sollten am 15. 4. ungefähr 220 Juden nach Kamionka und Ostrow-Lubelski, ${ }^{34}$ wo bereits Juden wohnen, transportiert werden. Nähere Einzelheiten konnten zunächst nicht festgestellt werden.

33 Išlo o transport z Trnavy. Čast’ mužov bola selektovaná v Lubline. K selekcii bližšie pozri GRUDZIŃSKA, Żydzi slowaccy v obozie koncentracyjnym na Majdanku, ref. 2, s. 63.

34 Pozri dokument 5. 
Žandárske stanovište Lubartów

Okres Lublin,

Oblast' Lublin

č. pod. den. 614/42

Lubartów, 14. apríla 1942

Žandárskej čate

$\mathrm{v}$ Lubline

Vec: Presídlenie Židov.

Dňa 9. 4. 1942 bolo z Lubartówa presídlených železnicou s tu neznámym ciel’om 650 Židov. Namiesto nich dorazilo do Lubartówa popoludní 13. 4. 1942 približne 900 z Bratislavy v Československu. Pre nedostatok ubytovacích kapacít má byt' 15. 4. do Kamionky a Ostrówa Lubelského, kde už Židia bývajú, prepravených asi 220 Židov. Bližšie podrobnosti sa doposial' nepodarilo zistit'.

BArch Ludwigsburg, B 162/1843, Bl. 52. Kópia, strojopis, 1 strana.

\section{Dokument 5}

Prípis žandárskeho stanovišt’a v Lubartówe žandárskej stanici v Lubline vo veci príchodu transportu zo Slovenska do Lubartówa zo 16. apríla 1942

Gend.-Posten Lubartow

Tgb. Nr. 626/42

Lubartow, den 16. April 1942

An

den Gendarmeriezug

in Lublin

Betreff: Umsiedlung von Juden.

Am Nachmittag des 15. April 1942 trafen in Lubartow weitere 680 Juden ein, von denen infolge Quartiermangel 280 nach Ostrow-Lubelski, 100 nach Kamionka und 60 nach Firloj ${ }^{35}$ verschubt [sic!] wurden. Bei den Juden handelt es sich um Frauen und Kinder, das männliche Geschlecht über 15 Jahren soll in Lublin behalten worden sein. Die Juden kamen aus Neutra in der Tschechoslowakei.

Žandárske stanovište Lubartów

č. pod. den. 614/42

Lubartów, 16. apríla 1942

Žandárskej čate

35 Správne Firlej. 


\section{$\mathrm{v}$ Lubline}

Vec: Presídlenie Židov.

Popoludní 15. apríla 1942 prišlo do Lubartówa d’alších 680 Židov, z ktorých pre nedostatok ubytovania bolo presunutých 280 do Ostrówa Lubelského, 100 do Kamionky a 60 do Firleja. Pri týchto Židoch ide o ženy a deti, mužské pohlavie nad 15 rokov bolo ponechané v Lubline. Židia prišli z Nitry v Československu.

BArch Ludwigsburg, B 162/1843, Bl. 53. Kópia, strojopis, 1 strana.

\section{Dokument 6}

Prípis oblastného komisariátu v Lubartówe okresnému náčelníkovi Lublin-vidiek týkajúci sa príchodu d'alších transportov zo Slovenska z 9 . mája 1942

Der Kreishauptmann Lublin-Land

Landkommissariat Lubartow

Tgb. Nr. 2388/42

Lubartow, den 9. Mai 1942

An den

Herrn Kreishauptmann Lublin-Land

in Lublin

Betr.: Umsiedlung von Juden aus der Slowakei.

Wie ich bereits fernmündlich berichtet habe, wurde mir am vergangenen Mittwoch vom Gouverneur des Distrikts, Bevölk.[erungswesen] u.[nd] Fürsorge mitgeteilt, dass am Donnerstag 1000 Juden aus der Slowakei eintreffen würden, sie würden in etwa 14 Tagen weiter transportiert. Am Donnerstag, den 7. Mai spät abends kam der Transport hier an; es waren 841 Personen, ältere Männer und Frauen mit Kindern, 199 Männer wurden in Lublin zurückbehalten. ${ }^{36}$ Dieser Transport mit Gepäck und Lebensmitteln besser ausgestattet als die früheren. Die Leitung der Umsiedlung ab Lublin hatte der SS-Obstf. Pohl, ${ }^{37}$ der auch anläßlich der Aussiedlung der hiesigen Juden am 9. April hier anwesend war.

Die Juden sind vorerst in früheren Gymnasien untergebracht worden. Ob und wann der Weitertransport erfolgt ist noch nicht geklärt.

Okresný náčelník Lublin-vidiek

36 Išlo o transport vypravený z Trebišova 4. mája 1942. Slovenský národný archív (d’alej SNA), fond (d’alej f.) Ministerstvo vnútra 1938 - 1945 (d’alej MV), kartón (d’alej k.) 227a, deportačný zoznam transportu č. 21.

37 SS-Obersturmführer Helmut Ortwin Pohl (1901 - ?), od 20, januára 1942 člen Globocnikovho štábu zodpovedného za realizáciu akcie Reinhardt. 
Oblastný komisariát Lubartów

č. pod. den. 2388/42

Lubartów, 9. mája 1942

Pánu okresnému náčelníkovi Lublin-vidiek

v Lubline

Vec: Presídlenie Židov zo Slovenska.

Ako som už telefonicky podal správu, minulú stredu mi guvernér oblasti, [oddelenie] obyvatel'stvo a sociálna starostlivost', oznámilo, že vo štvrtok dorazí 1000 Židov zo Slovenska a že asi o 14 dní budú transportovaní d’alej. Vo štvrtok 7. mája neskoro večer sem prišiel transport. Bolo to 841 osôb, starších mužov a žien s det'mi, 199 mužov zostalo v Lubline. Pokial' ide o batožinu a potraviny, bol tento transport vybavený lepšie ako predošlé. Presídlenie od Lublina viedol SS-Obstf. Pohl, ktorý tu bol prítomný aj počas vysídl'ovania tunajších Židov 9. apríla.

Židia sú predbežne ubytovaní v niekdajších gymnáziách. Či a kedy sa uskutoční d'alší transport nie je ešte jasné.

BArch Ludwigsburg, B 162/1843, Bl. 83. Kópia, strojopis, 1 strana.

\section{Dokument 7}

Prípis dopravnej kontroly Generálneho riaditel'stva východnej železnice v Krakove slovenskému ministerstvu dopravy a verejných prác vo veci vyúčtovania transportov z Michaloviec smerujúcich pôvodne do Nałęczówa z 15 . mája 1942

Verkehrskontrolle I

der Generaldirektion der Ostbahn Krakau, Bosackastrasse 4

An das

Ministerium für Verkehr

und öffentliche Arbeiten

in Bratislava

Unser Zeichen VkI/30 Tag 15. 5.42

Betreff: Beförderungskosten für Sonderzüge.

Der am 6. 5. 42 von Michalovce nach Naleczow abgefertigte Sonderzug mit 1002 Personen wurde nach Lukow weitergeleitet.

Der am 8. 5. 42 von Zilina ${ }^{38}$ nach Naleczow abgefertigte Sonderzug Da 89 wurde von Naleczow nach Miedzyriec Podlaski weiterbefördert.

38 Transport bol vypravený z Michaloviec so zastávkou v koncentračnom stredisku v Žiline. 
Wir bitten, für beide Sonderzüge die Kosten nach den neuen Bestimmungsbahnhöfen einzuziehen und durch die Abrechnung zuzuscheiden.

Dopravná kontrola I

Generálneho riaditel'stva východnej železnice Krakov, Bosacka ulica 4

Ministerstvu dopravy

a verejných prác

v Bratislave

Naša značka $\mathrm{VkI} / 30$

Den̆ 15.5 .42

Vec: Prepravné náklady za osobitné vlaky.

Osobitný vlak vypravený 6. 5. 42 z Michaloviec do Nałęczówa s 1002 osobami bol prepravený d’alej do Łukówa.

Osobitný vlak Da 89 vypravený 8. 5. 42 zo Žiliny do Nałęczówa bol z Nałęczówa zaslaný d’alej do Międzyrzeca Podlaskeho.

Žiadame o zarátanie nákladov za oba osobitné vlaky podl’a nových staníc určenia a o ich zúčtovanie.

ROTHKIRCHEN, Livia. The destruction of Slovak Jewry. Jerusalem: Yad Vashem, 1961, dokument 31 .

\section{Dokument 8}

Svedectvo Jozefa Schnitzera zo Sabinova zo 17. 8. 1943 o deportácii do geta Rejowiec, väznení v tomto gete, následnej deportácii do vyhladzovacieho tábora Sobibor a selekcii do pracovného tábora Krychów

Správa zo Slovenska deportovaného a vrátivšieho sa Žida.

21. mája 1942 odišiel náš transport pozostávajúci z 1000 duší zo Sabinova cez Žilinu Čadcu priamo do Pol'ska. Na hraniciach prevzala nás nemecká bezpečnostná služba /SD/ iba podl'a čísel tak, že muži nastúpili na stanici, ked’že ženy boli spočítané vo vozňoch. Po d'alšej asi 2 - 3 dňovej ceste vyvagónovoli nás v Rejowietz - Lubelski. ${ }^{39}$ Za celej cesty trpeli sme ohromným nedostatkom vody, nakol'ko sme počas celej cesty dostali iba dva razy vodu. Potraviny sme nedostali žiadne, mali sme ale dost' potravín so sebou. V Rejovci /Rejowietz/ prevzali nás: inšpektor vodného hospodárstva v Cholmi ${ }^{40}$ Ing. Holzheimer ${ }^{41}$ a obvodný náčelník SA, ako aj 9 členov židovskej poriadatel'skej

39 Rejowiec.

40 Chełm.

41 Wasserwitschaftsinspekteur. 
služby /OD/42 Rejowietz pod vedením najstaršieho medzi Židmi a velitel’a OD Kesslera z Brna, ktorí nám boli nápomocní.

Nasledovného dňa, 27. mája prišiel k nám rovnako vel'ký transport zo Stropkova ${ }^{43}$ a 28. mája tiež taký transport z Humenného. ${ }^{44}$ Bolo nás teda 3000 Židov zo Slovenska, Rejowecki Židia boli vyst’ahovaní z Rejowietz na Chol Hamoed Pessach, ${ }^{45}$ takže zastihli sme v gete zo starého židovského obyvatel'stva iba 300 duší. K tomu pridružilo sa asi 60 Židov z Protektorátu a niekol'ko žien z Nitry /Slovensko/, ${ }^{46}$ ktorých transporty boli medzitým z Rejowietz vyst'ahované.

Ako byty bola nám pridelená čast' bývalých židovských domov. Mali sme vel'mi málo miesta, takže v miestnosti 3x4 [m] bývalo 20 - 25 osôb. Po 8 dní nikto sa o nás nestaral. Boli sme bez dozoru, panoval nepopísatel'ný neporiadok, o výživu sa tiež nikto nestaral. Z potravín, ktoré nám dala odbočka ÚŽ v Žiline, boli najdôležitejšie - hlavne však korene - okresným náčelníkom SA nám odňaté a uskladnené v škole. Teprve po 15 dňoch boli nám tieto vrátené, avšak v stave, $v$ ktorom sa už nedali použit'. Konečne boli sme všetci 3000 Židia vyzvaní, aby sme sa hlásili k vysušovacím prácam močiarov. K práci boli pripustení iba mladí, silní l'udia. Otcovia 3 detí neboli pripustení, takže spolu prišlo 450 mužov k práci. Títo boli aj stravovaní a dostávali denne $25 \mathrm{dkg}$. chleba, tenkú krupičkovú polievku a k večeri čiernu kávu. Ďalších 500 - 600 l’udí mladých bolo bez ohl'adu na ich rodiny odoslaných do susediacich táborov ako n.pr.

Sawin, Szaiczice ${ }^{47}$ a Cholm

/v tomto poslednom k švadrone SA./ Výber týchto mužov previedli už spomenutí Židia z OD, ktorí sa nechali korumpovat' rôznymi im darovanými predmetmi. Tu musím poznamenat', že židovská rada pozostávala z rôznych elementov. Treba vyzdvihnút' obetavú pomoc pi. Gen. riad. Forbathovej a pi. Fémes z Nitry. To však nedá sa povedat' o pi. Kaufmannovej a Singerovej, údajne sestier, tiež z nitrianského transportu. O takto tam pozostavších asi 2.000 Židov sa ani nad’alej nikto nestaral, zostali úplne bez potravín. Konečne zariadila židovská rada z Cholmu po 3 až 4 týždňoch l'udovú kuchyňu, ktorá proti zaplateniu 50 grošov vydávala obed pozostávajúci z polievky. Židovská rada v Cholme bola toho času pod vedením vel'mi poriadneho a váženého Žida menom Fränkel, ktorého neskoršie spolu s jeho rodinou zastrelili.

42 Ordnungsdienst.

43 Transport č. 34 vypravený 23. 5. 1942 z Bardejova, v ktorom bolo deportovaných mnoho Židov z okresu Stropkov, nakol'ko mesto Stropkov nemá železničné spojenie. SNA, f. MV, k. 227a, deportačný zoznam transportu č. 34.

44 Transport č. 35 vypravený 24. 5. 1942 z Popradu. Mnoho Židov v tomto transporte pochádzalo z okresu Humenné. SNA, f. MV, k. 227a, deportačný zoznam transportu č. 35.

45 Ide o hebrejské pomenovanie dní medzi prvým a posledným dňom sviatku Pesach. Prvá vel'ká likvidačná akcia v gete Rejowiec sa uskutočnila 7. 4. 1942. Židia boli zhromaždení na trhovisku a odvezení do vyhladzovacieho tábora v Bełżeci. SILBERKLANG, ref. 5, s. 316.

46 Ide zrejme o osoby deportované do geta Rejowiec v transporte č. 12 vypravenom dňa 15. 4. 1942 z Nitry.

47 Szajczyce. 
V dôsledku nepostačujúcej stravy a nemožných sanitných podmienok mnoho l’udí ochorelo týfom, /úplavicou/, červienkou a pod. Mnoho starších l'udí zomrelo.

Istého večera prišiel opilý pol'ský strážnik do bytu lekára Dr. Grossmanna /Sabinov/, ktorý sa práve bol vrátil od chorého a žiadal si náramkové hodinky Dr. Grossmanna. ${ }^{48}$ Ked' tento nechcel hodinky vydat', vznikla medzi obidvoma hádka, v ktorej strážnik ohrozil Dr. Grossmanna zbraňou, vznikla bitka. Židovská OD, ako aj Židia zo susedných domov prišli s pomocou. Strážnikovi vráteno jeho zbraň, načo tento vystrelil 3 razy do vzduchu. Okamžite bola tu pol'ská polícia, ${ }^{49}$ ktorá zatkla obyvatel'ov domu Dra. Grossmanna, medzi inými 5 členov OD, Dr. Grossmann pokúsil sa o útek, bol ale zranený a hned' nato zastrelený. Zatknutých 24 osôb druhého dňa bolo popravených za „komunistickú vzburu“. Medzi tými boli:

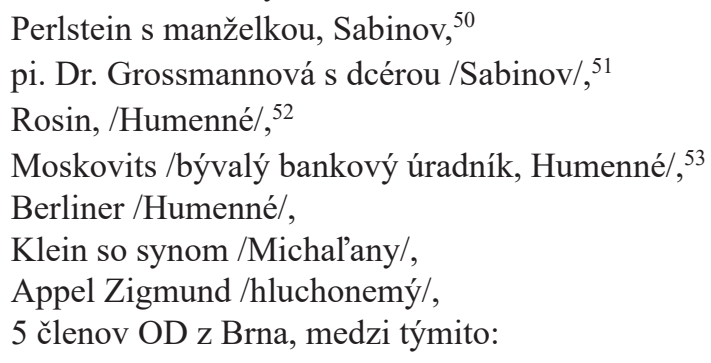

48 MUDr. Zoltán Grossmann (1899), bývalý obvodný a nemocenský lekár v Širokom. Od júla 1940 mal ministerstvom vnútra Slovenskej republiky zakázané vykonávat' lekársku prax. Odišiel do Sabinova. Bol deportovaný zo Slovenska v transporte č. 33, vypravenom dňa 22. 5. 1942. SULAČEK, Jozef. Biele plášte. Tragické osudy židovských lekárov na Slovensku $v$ obdobi druhej svetovej vojny. 2. čast'. Bratislava: Slovenské národné múzeum - Múzeum židovskej kultúry, 2006, s. 40. ISBN 808060164X; SNA, f. MV, k. 227a, deportačný zoznam transportu č. 33 .

49 Pol'ská polícia v Generalgouvernenmente (Polnische Polizei im Generalgouvernement), miestnym obyvatel'stvom podl'a farby uniformy hovorovo označovaná aj „policija granatowa“ (tmavomodrá polícia). Išlo o policajné jednotky zriadené nemeckými okupačnými orgánmi na jeseň roku 1939. Pol'ská polícia pôsobila ako miestna polícia a bola podriadená nemeckej poriadkovej polícii (Ordnungpolizei). Jej príslušníci sa zúčastňovali aj na strážení židovských get či potláčaní čierneho trhu. Granatowa policja. Dostupné online: https://sztetl. org.pl/pl/slownik/granatowa-policja.

50 Koloman Perlstein a Anna Perlsteinová. Obaja boli deportovaní zo Slovenska v transporte č. 33, vypravenom dňa 22. 5. 1942. SNA, f. MV, k. 189, spis 1, Sabinov - Súpis Židov; SNA, f. MV, k. 227a, deportačný zoznam transportu č. 33.

51 Mária Grossmannová (1899) a dcéra Lily Grossmannová (1928) boli deportované spolu s Dr. Zoltánom Grossmanom v transporte č. 33. SNA, f. MV, k. 227a, deportačný zoznam transportu č. 33.

52 Eugen Rosin (1905), bývalý záhradník v Humennom. Bol deportovaný v transporte vypravenom z Popradu dňa 24. 5.1942. SNA, f. MV, k. 184, Humenné - Súpis Židov; SNA, f. MV, k. 227a, deportačný zoznam transportu č. 35 .

53 Emanuel Ferdinand Moškovič (1905), bývalý úradník v Humennom. Bol deportovaný v transporte č.35, vypravenom dňa 24. 5.1942 z Popradu. SNA, f. MV, k. 184, Humenné - Súpis Židov; SNA, f. MV, k. 227a, deportačný zoznam transportu č. 35. 
Reiss,

Kessler.

9. augusta 1942 o 6. hod, ráno vydalo žandárstvo rozkaz k nastúpeniu. Celé židovské obyvatel'stvo, tak geto, ako aj pracovný tábor /spolu asi 2700 osôb/ muselo nastúpit' na námestí pred školou /s batohmi/. Všetci, ktorí tomuto rozkazu v dôsledku choroby alebo slabosti sa podrobit' nemohli, boli zastrelení v bytoch. Ten istý osud stihol tiež nemocných v žid. „,nemocnici“, medzi aj Dra. Seböka zo Sabinova, ${ }^{54}$ ktorý bol chorý týfusom. Okolo 10 hod. boli starší l'udia, ktorí unavení uložili batohy na zem a na týchto si sadli, zastrelení zozadu do väzov SS mužmi. Tak zomrelo 30 - 40 l'udí. Potom bol daný rozkaz k odpochodovaniu. Spredu išli ženy, potom muži. Lekár Dr. Borkenfeld zostal ako posledný. Vyzval som ho aby išiel dopredu, lebo bolo nebezpečne zostat' v zade. „To je mojou povinnost'ou, som lekár,“ povedal. Sotva sme urobili 30 - 40 krokov, bola vystrelená salva z pušiek a strojových pistól, zl’ava. Naše riady sa silne zriedili. Medzi inými padli:

\author{
Dr. Abraham Borkenfeld, ${ }^{55}$ \\ Dr. Jozef Deutsch $/$ Sabinov/ $/{ }^{56}$ \\ Ing. Bergstein /Sabinov/, ${ }^{57}$ \\ pi. Naglova /Sabinov/, \\ Horowitz s manželkou/Sabinov/, s. Holländerová /Sabinov/.
}

Neskoršie hovoril mi bývalý člen židovskej rady v Rejovci /Rejowietz/, pol'ský Žid menom Holzblatt, ktorý sa vtedy nejakým spôsobom zachránil, že pri tejto strel'be stratilo život 700 Židov.

V Rejovci zostala vtedy iba malá hŕstka Židov, robotníkov v susednej továrni - cukrovari, ktorí ako sme sa neskoršie dozvedeli, boli preložení do Travník ${ }^{58} \mathrm{k}$ prácam torfovým. ${ }^{59}$ Medzi nimi boli:

Béla Landsmann, Sabinov,

Dr. Dezider Schön, Sabinov,

10 mužov zo Stropkova.

54 MUDr. Eugen Sebök (1885), lekár. Deportovaný v transporte č. 34, vypravenom 23. 5. 1942 z Bardejova. United States Holocaust Memorial Museum Archives (d'alej USHMMA), Record Group (d'alej RG) - 57.001 M, reel 15, card No. 3091.

55 MUDr. Abrahám Borkenfeld (1893). Vojenský a praktický lekár v Sabinove. Od 1. 7. 1940 mal na Slovensku zakázané vykonávat' lekársku prax. Bol deportovaný spolu s manželkou a diet'at'om v transporte č. 33, vypravenom dňa 22. 5. 1942. SULAČEK, ref. 48, s. 19; SNA, f. MV, k. 189, Sabinov-Súpis Židov; SNA, f. MV, k. 227a, deportačný zoznam transportu č. 33.

56 Dr. Jozef Deutsch (1894), advokát. Deportovaný v transporte č. 33, vypravenom dňa 22. 5. 1942. SNA, f. MV, k. 189, Sabinov- Súpis Židov; SNA, f. MV, k. 227a, deportačný zoznam transportu č. 33 .

57 Ing. Eugen Bergstein (1889). Deportovaný v transporte č. 33, vypravenom dňa 22. 5. 1942. SNA, f. MV, k. 189, Sabinov - Súpis Židov; SNA, f. MV, k. 227a, deportačný zoznam transportu č. 33 .

58 Trawniki, kde sa nachádzal pracovný tábor.

59 Ťažba rašeliny. 
Na stanici v Rejovci prevzali nás t. zv. „Čierni Ukrajinci“. ${ }^{60}$ Vtlačili nás do vozňov pre dobytok už tam pripravených, po 120 až 150 do jedného vozňa, bez akejkol'vek evidencie. Dvere zavreli a ostali sme na stanici do 8-ej hod. večer. Z pomedzí nás vyvolano 25 mužov, ktorí mali pozbierat' odhodené batohy a tieto dat' do vozňov. Týchto pri práci „Čierni Ukrajinci“ “ bili a šikanovali. Vo vozňoch bolo neznesitel'ne horko - bol to august - nemali sme ani vody, ani vzduchu. Ženy odhodili zo seba šaty, stáli sme vedl'a seba ak slede, lebo nebolo miesta ani na ten najmenší pohyb. 150 osôb sa tu udusilo a zomrelo, iba v mojom vozni 20 osôb, medzi nimi aj l’udia mladí a silní, ako n.pr.

Róbert Riemer /15-ročný, vel'mi silný/,

Samuel Grün /bývalý mäsiar/.

Okolo 1/2 1 v noci sme prišli do Sobibora. Tu privítali nás SS s nahajkami. Konečne dostali sme niečo vody, k jedeniu nič. Potom odviedli nás k smrekovej aleji. Ženy boli dirigované na pravú, my na l'avú stranu. 25 z pomedz[i] nás bolo určených na vyprázdnenie od mítvol a balíkov. Týchto mužov sme potom viac nikdy nevideli. Na druhý deň ráno videli sme, ak[o] väčšia čast' žien odchádzala do d’alej ležiaceho dvora. O 8 ej hod. prišiel k nám poručík SS, ktorý nás vyzval, aby sa hlásili t[í], ktorí pracovali pri močiaroch. Hlásilo sa asi 100 mužov, k tomu prišlo asi 50 žien, a tak vznikla skupina o asi 155 l'udioch. Poručík vyjadril sa k tejto skupine: „Ste novonarodení.“ Z pozostavšiej skupiny boli potom vybraní mechanici, zámočníci a hodinári, ostatných stretol ten istý osud, ako väčšinu žien; odišli do d’alej ležiaceho dvora.

155 kandidátov práce odišlo potom do Osowy, kde strávili sme noc. Tamojšie židovské vedenie prijalo nás dobre, dostali sme poriadne $\mathrm{k}$ jedeniu. Tam našli sme asi 500 nemeckých a českých Židov. Židovská polícia odviedla nás potom do Krychova. ${ }^{61}$ Po ceste prešli sme cez statok Hansk, kde sme videli asi 100 židovských dievčat pracujúcich pri žatve. Tieto mali sa pomerne dobre.

Krychov je trestaneckým táborom, zriadeným už predtým pol'skou vládou v močariskách. Okolie je už dostatočne Židmi odvodnené. Pri našom príchode bol stav asi 1200 osôb, medzi tými asi 400 Čechov, 200 Slovákov, ostatní Poliaci. Bytové pomery boli neopísatel'ne zlé. V budovaných barakoch 60 x 40, bývalo nás po 200 osôb. Nemali sme ani slamu, ani deky. Žiadna príležitost' k umývaniu sa, ohromná špina a hmyz. Mali sme tol'ko vší, že tieto doslovne pokryli naše telo. Proti tomu nebolo nijakej pomoci. Strava pozostávala:

z 15 dkg. chleba,

60 Hovorové označenie príslušníkov pomocných strážnych oddielov, ktorých nacisti regrutovali spomedzi zajatých príslušníkov Červenej armády a cvičili v tábore Trawniki. Kvôli miestu výcviku ich príslušníci SS často volali „Trawniki-Männer“. Etnické zloženie týchto strážnych oddielov bolo pestré, ale pre značné zastúpenie Ukrajincov boli Židmi a pol'ským obyvatel'stvom často označovaní ako „Ukrajinci“, prípadne „Čierni“a a „Čierni Ukrajinci“, čo reflektovalo farbu ich uniforiem. Tieto jednotky sa podiel’ali na likvidáciách get, deportáciách Židov z get do vyhladzovacích táborov a na strážnej službe vo vyhladzovacích táboroch. Bližšie pozri BLACK, Peter. Foot Soldiers of the Final Solution: The Trawniki Training Camp and Operation Reinhard. In Holocaust and Genocide Studies, 2011, roč. 25, č. 1, s. 1 - 99. ISSN 87566583; OLEKSY-ZBOROWSKI, ref. 8, s. 43 - 44.

61 Krychów. 
1 polievky z kapustových listí bez tuku a soli, čiernej k[á]vy.

Z praxe sme už vedeli, že táto strava stačí k hladovej smrti behom š[i]estich týždňov. Po krátkom čase opuchli väčšine z nás nohy a tváre. Okrem toho panoval tam týfus a červienka. Prinajmenšom týfus mal každý z nás. Denne mali sme prinajmenšom 12 smrtných prípadov. Zo 155 osôb, ktoré prišli so mnou zomrelo v dôsledku týchto pomerov 60 osôb. Hoci práca nebola príliš t’ažká, nemohli sme ju vykonávat', lebo sme boli telesne celkom oslabení. Lekár nemal právo uznat' n[i]ekoho chorým. S horúčkou $39\left[{ }^{\circ} \mathrm{C}\right]$ museli sme k práci. Ked' sa niekto predsa len dostal do nemocnice, spočívalo ošetrovanie v tom, že mohol tam iba ležat'. Nedostalo sa ani lieky, ani stravu pre chorých, kto chorobu prešiel, tak ten ju prešiel, kto nie, ten nie.Za t'ažké peniaze mohlo sa eventuálne dostat' aj lieky, peniaze sme však nemali.

Dňa 16. októbra oznámili nám, že čast’ robotníkov pôjde do „židovského mesta“Wlodawa n/Bugom $/ 25 \mathrm{~km}$ od Krychowa/. Pre toto presídlenie vyvoleno starších, chorl'avých [l']udí, ktorí prácu dobre neznášali a detí. Tiež nemocnica bola vyprázdnená a l'udia odoslaní do Wlodawy. Ludia boli odoslaní do [Wlodawy] bez batohov a bez obuvy /gumové čižmy používané pro práci, boli vlastníctvom tábora a nedovolili, aby si dotyční doniesli svoju obuv/. 4 dni po príchode do Wlodawy bolo celé židovské obyvatel'stvo odoslané z Wlodawy do Sobibora.

Po nejakom čase boli k nám preložené tábory Ujazdov a Hansk na prezimovanie, v dôsledku čoho sa bytové pomery ešte viac zhoršili a vskutku nedalo sa už vydržat'.

9. decembra [1942] bolo nám náhle oznámené, že budeme presídlení. Bolo vybraných 100 osôb ku ktorým sa potom pridružilo ešte 10, ktoré mohli zostat'. Všetci ostatní boli odvedení.

Zostalo niekol'ko dievčat, resp. žien z Nitry, medzi ktorými:

Taussig Piroska, Nitra, ${ }^{62}$

Fürst Jozsa, Nitra, ${ }^{63}$

Fürst Eva, Nitra, ${ }^{64}$

Gartner Edith,Nitra,

? Mirjam, Nitra,

Wertheimer Hanka, Český Tešin - Nitra /Chaluzah/,

Weiss Jolan, Ružomberok,

Steiner Malvina a syn, Nitra,

d’alej niekol'ko českých a nemeckých žien a dievčat. Z mužov zo Slovenska, zostal som iba sám, z Čiech:

Fritz Singer, Praha,

Kurt Rhein, Tepl. Schönau-Praha,

62 Piroška Tausigová (nar. 1909), deportovaná v transporte č. 12, vypravenom z Nitry dňa 15. 4. 1942. SNA, f. MV, k. 227, deportačný zoznam transportu č. 12.

63 Jozefína Fürstová (nar. 1898), deportovaná v transporte č. 12, vypravenom z Nitry dňa 15. 4. 1942. SNA, f. MV, k. 227, deportačný zoznam transportu č. 12.

64 Eva Fürstová (nar. 1922), deportovaná v transporte č. 12, vypravenom z Nitry dňa 15. 4. 1942. SNA, f. MV, k. 227, deportačný zoznam transportu č. 12. 
ostatní boli pol'skí Židia. Skupina vdiači vel'mi mnoho Piroske Taussigovej z Nitry, ktorá si vedela zadovážit' výnimočné postavenie v správe, a ktorá pomáha kde sa len dá. Okolnost', že mohlo tam zostat' tol'ko dievčat treba vd'ačit' tiež iba jej.

Na jar bol náš tábor zväčšený príchodom d'alších pol'ských Židov. V júni 1943 boli likvidované tábory Ossowa, Sawin, Szaiczice a Luta. Zvyšok prišiel k nám a náš počet sa zvýšil na 533 osôb. Okrem toho bolo v Hansku asi 100 - 110 žien a 5 mužov.

Zo Sawina prišli k nám, medzi inými, tieto osoby:

Sestry Mari a Bözsi /z Nitry/ rodinné meno neznám/,

Pani Maca /rod. meno neznám, asi 30 ročná, Nitra, jej muž bol údajne krajčírom/,

Nelly /rod. meno neznáme, krajčírka Nitra/,

pani Friedová /býv. majitel'ka obchodu s módnym tovarom, výbavy pre nevesty, Piešt'any/,

Dukes /Piešt'any-Nitra/,

Dr. Sinay a pi., Stropkov, ${ }^{65}$

Dym /štátny úradník, Vel’. Kapušany/,

Bruder, Snina,

Dr. Szilard, lekár /Prešov/, ${ }^{66}$

pani Edita Rauchwergerová/Sp. Nová Ves/,

d'alej boli medzi nimi:

pani Nowak, s dcérami Ruth a Mimi Brand, Praha,

Roubitschek Vera, Praha,

Roubitschek Alica, Praha,

Kaffková Hanka, Plzeň,

príbuzný p. Júliusa Baslera zo Sabinova, na ktorého meno sa už nepamätám.

Od roku 1943 sa pomery v Krychowe značne zlepšili. Po 9. decembri 1942 dost[á]vali sme prídel chleba 40 - $50 \mathrm{dkg}$. denne, d’alej hustú zemiakovú polievku k obedu. Dostali sme poriadne železné postele, hygienické pomery sa tiež zlepšili, mohli sme sa umývat'. Zdravotný stav sa zlepšil a mali sme potom iba 3 smrtné prípady z pozostavších 110 osôb, a to:

Büchler, Bratislava-Nitra, býv. kaviarnik /príbuzný štátneho zástupcu Fodora v Nitre, zomrel na rakovinu,

Donath, Prievidza /55 ročný/,

pi. Handtová, Viedeň /dcéra 18 ročná v Krychowe/,

3 d’alší nemocní, boli zastrelení zástupcom velitel'a tábora, ktorý sa nachádzal na dovolenej

65 JUDr. Samuel Szinai (nar.1897, v niektorých prameňoch aj „Sinaj“), ktorého manželkou bola Blanka Szinaiovou (1903). Obaja žili pred deportáciami v Stropkove. Deportovaní boli 23. mája 1942 v transporte vypravenom z Bardejova. SNA, f. MV, k. 189, Stropkov - Súpis Židov; USHMMA, RG - 57.001 M, reel 15, card No. 2540.

66 MUDr. Andrej Szilard (nar. 1913), ktorý bol deportovaný v transporte č. 26, vypravenom dňa 12. 5. 1942 zo Žiliny, SNA, f. MV, k. 227a, deportačný zoznam transportu č. 26. 
Hopkovits alebo Heimovits zo Stropkova, bývalý zamestnanec firmy Kulik, pol'skí Židia.

V marci po zväčšení tábora sa strava opät zhoršila. Prídel chleba klesol na 15 dkg denne, k obedu iba zeleninová polievka, úplne bez tuku.

V apríli 1943 hovorilo sa u nás, že prijdu k nám Židia holandskí a belgickí, čo potvrdila aj správa tábora. Avšak neprišli. O osude týchto l'udí počul som od železničného robotníka následovné: Transporty z Holandska a Belgicka prišli vo vel'mi dobrom stave. V protivenstve $\mathrm{k}$ naším transportom, išli tieto aj druhou triedou, na väčších stanicách dostávali stravu a aj biely chlieb. Privedli ich však všetkých do Sobibora. Niekol'kých starších a slabších l'udí odoslano spät' do Holandska a Belgicka s odôvodnením, že možno použit' iba dobré pracovné sily. Tým mal sa zlomit’ odpor u belgických a holandských Židov proti deportácii s odôvodnením, že sa Židia použijú iba k práci. Pôvodne sa hovorilo, že títo Židia rovnako ako Židia z iných štátov budú dirigovaní k práci,

SD ich však neuvol'nila, resp. neuvol'nila ani jednoho, všetci boli v Sobibore popravení. V okolí Sobibora pozoruje sa vždy v noci oheň a v d’alekom okruhu cíti sa smrad spálených vlasov. Rôzne príznaky ukazujú na to /a obyvatel'stvo tiež to tvrdí/, že mítvoly, ktoré boli predtým zničené elektrinou a plynom a pochované, teraz sa exhumujú a pália, aby nezostal po nich ani znak.

V roku 1942 trestano dezercie t'ažkými represiami. Väčšinou utekali pol'skí židia oboznámení s miestnymi pomermi. St’ahovali sa do lesov, tvoria tam bandy a žijú z lúpeže. V poslednom čase trestajú iba dezertéra, ked' ho chytia.

Zo Savina, ked' ešte tento tábor existoval, utiekol Dr. Béla Sobel z Pečovskej Novej Vsi, ako aj Feiner. Obidvoch chytili a Sobel bol popravený. Feiner, ktorého priviedli spät' do Sawina, utiekol opät' a od toho času nič sa o ňom nevie. Dezertoval tiež Lajos Klein z Michaloviec, jeho osud je neznámy.

Podl'a mojich informácií pracuje v Lubline Majdanek asi 8000 Židov /osemtisíc/ pri prácach vodovodných, kanalizačných a stavebných. Ako som počul, pracujú títo l’udia v trestaneckých šatoch. Armin Goldstein zo Sabinova mi oznámil, že Mano Goldberg v Majdankach zomrel.

YVA, M.5/193, Originál strojopis, 5 strán.

\section{Dokument 9 \\ Svedectvo Šarloty Adlerovej deportovanej do Lublinskej oblasti z Medzilaboriec 19. mája 1942 z 26. júla 1945 v Bratislave}

Náš transport došiel do Konskej Voli ${ }^{67}$ (40 km od Lublina). Železničná stanica Pulawy, odkial' sme išli pešky do Konskej Voli. Tu sme bývali v tej vel'kej dedine v opustených domoch po $4-5$ rodín $\mathrm{v}$ jednej izbe. Židia, ktorí pred nami tam bývali, boli odvlečení

67 Końskowola. 
na neznáme miesto. ${ }^{68}$ Ihned' na druhý deň nás poslali na práce. Práca bola vel'mi t’ažká. Pracovalo sa na píle a všelijaké vonkajšie komandá.

Ja som bola deportovaná a aj žila som spolu s mojím otcom [...], mamičkou [...] a s dvoma bratmi [...]. Pracovat' musel každý, aj môj brat. Jedného dňa traja chýbali v práci. Židovská rada dostala rozkaz doviest' tých troch Židov, ale len jedného našli. Gestapo ihned' prišlo robit' poriadok a zastrelili koho chytili na ulici. Tak aj jedného židovského chlapca, ktorého stretli popoludní, napriek tomu, že mal legitimáciu, že bol zadelený do nočnej šichty. Aj po bytoch chodili. Pol'skí vojenskí zajatci Židia, ktorí tiež boli zaistení $\mathrm{v}$ tejto dedine, museli pochovat' obete tohto pogromu a nad hrobom museli tancovat' a spievat'.

Ja som pracovala na zariadení rybníka, majetok riaditel'a von Panowitscha, gestapák, ${ }^{69}$ ktorý chodil v civile, manželka jeho bola údajne rodina Hitlera. Počas tohto pogromu ja som tiež bola doma, ale ku mne neprišli, lebo na dverách som mala napísané, že pracujem pre von Panowitscha a jeho sa vel'mi báli. Moja mamička tiež pracovala na tomto komande a ako mamička jednej robotníčky bolo jej dovolené pracovat' v kuchyni, čo bolo o niečo l'ahšie zadelenie. Von Panowitsch bol vel'mi vel'ký sadista. Jedného Žida [...] z Medzilaboriec nechal zbit' (25), lebo mu údajne ukradol jedno vajíčko. Len preto ho nezastrelil, lebo vel'mi dobre pracoval. Ale od toho času, že 60-ročný J. dostal tie bitky, už nebol práceschopný ako predtým.

V sept. 1942 došli opití gestapáci z Lublina a robili pogrom v dedine.${ }^{70}$ Striel'ali koho len mohli. Len vd'aka von Panowitschovi táto akcia bola zastavená.

My sme dostali denne $4 \mathrm{zl}$ a okrem toho mesačne $3 \mathrm{~kg}$ múky, $20 \mathrm{dkg}$ cukru.

Gestapáci: Wagner, Gedo a Seedorf (dozorca píly).

SS-inšpektor Rybacky (Ukrajinec) nás strašne bil pri práci.

15. okt. 1942 bol takzvaný Vernichtungstag. Všetci zaradenci museli nastúpit' na trhovisku, len niekol'kých poslali autami do Lublina, ostatných nakladali do vagónov a odviezli na neznáme miesto. Medzi tými boli aj moji rodičia a súrodenci. Ja som patrila k tomu malému počtu, ktorí mohli ostat' v Konskej Voli ako zamestnanec von Panowitscha. Ale to tiež netrvalo dlho. 22. okt. 1942 aj ten zostatok nás poslali do Lublina-Majdanek. ${ }^{71}$

Autami sme cestovali. Ked' sme sa priblížili k Majdanku, už sme cítili zápach krvi. A ked' sme došli do tábora, všade boli také potôčky krvi. Tábor bol takmer prázdny. 15. okt. 1942, ked' bol v Konskej Voli ten Vernichtungstag, v ten deň v celom dištrikte

68 Dňa 8. mája 1942 boli deportovaní do vyhladzovacieho tábora Sobibor.

69 Skutočnú identitu sa nám nepodarilo zistit'.

70 Išlo o príslušníkov 3. roty 101. záložného policajného práporu.

71 K priebehu likvidácie geta pozri BROWNING, Christopher. Ganz normale Männer. Das Reserve-Polizeibateillon und die »Endlösung" in Polen. Reinbek bei Hamburg: Rowohlt, 1993, s. 158 - 160. ISBN 3498005693. Podl'a Browningovho opisu bolo $800-1000$ l'udí (ženy s det'mi a starci) zastrelených v lese ned’aleko obce. Osoby vyselektované na prácu sa dostali do lublinského pracovného tábora, nie do Majdanku. Čast' židovského obyvatel'stva bola deportovaná do Sobiboru. SZCZYGIEŁ, Ryszard (ed.). Dzieje Końskowoli. Lublin: Końskowolskie Towarzystwo Regionalne, 1988, s. 107. 
Lublin vyvraždili Židov.72 Ja som dostala č. 1310. Pracovala som na komande kanalizácia. Robota bola vel'mi t’ažká. SS-manky nás vel'mi bili. Ale bola som tu len 3 týždne. Potom nás poslali do Lublina - mesto „Letovište““ ${ }^{73}$ Tu som dostala č. 7. Sem došli celé vlaky so šatstvom a inými predmetmi. ${ }^{74} \mathrm{Ja}$ som bola zadelená $\mathrm{k}$ sortírovaniu tohto šatstva. Práca bola t’ažká z toho dôvodu, že nás vel'mi honili. U koho našli zlato, ihned' [ho] obesili. V januári 1943 bola prvá vel'ká selekcia. A od toho času už nasledovali väčšie či menšie selekcie.

SS-Oberscharführer Winter, SS-Unterscharführer Gollek z Katovíc.

Potom som bola zadelená do Wäscherei. Tu som sa už mala trošku lepšie, pracovala som pre SS-Ukrajincov a dostala som aj z ich stravy. Pozdej nám tú stravu zarazili.

27. okt. 1943 prišiel do tábora SS-Unterscharführer Schwarz, že potrebuje l’udí na svoje komando. Mohli sme sa hlásit' dobrovol’ne. Ked’že som vel'mi hladovala, hlásila som sa tiež. 100 mužov a 52 žien nás spolu odviezli do Milejowa, fabrika marmelády pod dozorom Wehrmachtu. V tejto fabrike pracovalo 100 mužov z tábora Trawniki. 3. nov. prišiel rozkaz Barackensperre a nemali sme byt' nikam odvezení. 5. nov. prišiel riaditel' továrne, že by sme ostali. Toho istého dňa poobede prišli SS-Ukrajinci z Trawnikov a nás odviezli do tábora autami. Ked' sme došli do tábora, mŕtvoly ležali po zemi. 10000 l'udí bolo zastrelených. ${ }^{75}$ Naši 200 muži museli zbierat' a spálit' tie mŕtvoly, a ked' boli hotoví s prácou a že ešte oheň horel, tí 200 muži boli postavení okolo ohňa a zastrelení. Túto poslednú akciu som sama nevidela, ani moje kolegyne, ale SD-Oberscharführer, iniciály S. J., nám to pozdej v jednej dobrej chvíli vyprával. Po tejto akcii my sme sa už mali dobre, pracovali sme málo (upratovanie barakov) a jest' sme mali úplne dost'.

1. júna 1944 nás poslali do Majdanku, kde som dostala č. 37. Boli sme asi 50 žien. Pracovali sme pol’nú prácu, komando Lagergut. Trošku lepšie už zachádzali s nami. SS-áci sami hovorili, že je zakázané bit’ a gazovat'.

V júli 1944 nás poslali do Auschwitzu.

$[\ldots]$

YVA, M.5/127, 38-41. Originál, strojopis, 3 strany.

72 Nešlo len o jeden deň. Na základe Himmlerovho rozkazu z 19. júla 1942 malo byt’ do konca roku vyvraždené takmer všetko židovské obyvatel'stvo v Generálnom Gouvernemente. Nažive malo zostat' len niekol'ko tisíc l'udí, vykonávajúcich otrockú prácu v zberných táboroch vo Varšave, v Krakove, Čenstochovej, Radome a Lubline. Vel'ká vyhladzovacia akcia zameraná na fyzickú likvidáciu židovského obyvatel'stva na území Generalgouvernementu sa uskutočnila 3. - 4. novembra 1943. Išlo o ,akciu Dožinky“ (Erntefest), počas ktorej nacisti v Trawnikach, Lubline (koncentračný tábor Majdanek) a Poniatowej popravili približne 42000 Židov. Pozri HEIBER, Helmut (ed.). Reichsführer! Briefe an und von Himmler. Stuttgart: DTV, 1970, dokument 126, s. 163 - 164; LIBIONKA, ref. 5, s. 230.

73 Tábor nútených prác pre Židov „Staré Letisko“ (Alter Flughafen) Lublin, v nemčine hovorovo nazývaný aj „Flugplatz“ .

74 Išlo o odev a predmety po zavraždených Židoch v rámci akcie Reinhardt v táboroch Belzec, Sobibor a Treblinka.

75 V rámci ,akcie Dožinky“ (Erntefest) bolo v tábore nútených prác Trawniky zavraždených okolo 6000 l'udí. 


\section{Dokument 10}

Výsluch svedka Imricha G. izraelskou políciou pre potreby trestného stíhania personálu koncentračného tábora Majdanek Štátnym zastupitel'stvom Düsseldorf 3. novembra 1965

$[\ldots]$

Frage: Wann waren Sie in Majdanek?

Antwort: Vom Ende März 1942 bis Juni 1942. ${ }^{76}$

Bei dem Landgericht in Frankfurt sagte ich nichts über Majdanek aus. ${ }^{77}$

Ich kam Ende März 1942 in das Lager Majdanek Feld I. Die obersten Erdschichten begannen auftauen und das Lager selbst war mitten auf Feldern aufgebaut und durch das Auftauen des Schnees gab es im ganzen Lagergelände knietiefen Kot. Die verschiedenen SS-Leute, unter diesen besonders der Rapportführer Abraham, ${ }^{78}$ die uns bewachten, nützten diesen Umstand aus, liessen uns auf allen Vier in dem Kot herumkriechen und schlugen uns mit Peitschen, die aus Gebetsschalen verfertigt wurden und an deren Ende man Bleikugeln einnähte. Ich erinnere mich an einen bestimmten Vorfall.

Es war etwa im April 1942 vormittags als Abraham die Insassen einer Baracke, alle älteren Leute, die an diesem Tag nicht arbeiteten, auf dem Appellplatz heraustrieb, der ebenfalls mit tiefem Kot bedeckt war. Ich selbst stand in dieser Stunde neben der Schuhwerkstätte und das in einer Entfernung von ca. 50 Meter vom Appellplatz und sah mit eigenen Augen wie Abraham die alten Leute in den tiefen Kot „Sport“ machen liess, d. h. er liess sie niederfallen und aufstehen und schlug sie unbarmherzig mit der Peitsche. Die Leute, die nicht mehr aufstehen konnten, schlug er weiter mit der Peitsche und trat auf ihre Köpfe mit seinen hohen Gummistiefeln bis sie vollständig in dem Kot einsanken und erstickten. Ich weiss nicht wieviel dabei umgekommen sind, da ich mich nachher versteckte, aber ich schätze, dass es etwa $10-15$ waren. Ich weiss nicht ob Abraham sein richtiger Name war, so wurde er aber von allen genannt.

$[\ldots]$

Otázka: Kedy ste boli v Majdanku?

Odpoved': Od konca marca 1942 do júna 1942.

Na Krajinskom súde vo Frankfurte som k Majdanku nevypovedal nič.

76 Dňa 30. júna 1942 bolo z KT Majdanek do KT Auschwitz prevezených 400 osôb. Medzi nimi sa nachádzal aj svedok. Pozri CZECH, Danuta. Kalendarium der Ereignisse im Konzentrationslager Auschwitz-Birkenau 1939-1945. Reinbek bei Hamburg: Rowohlt Buchverlag, 1998, s. 238. ISBN 9783498008840.

77 Išlo o svedectvo počas 1. osviečimského procesu pred Krajinským súdom vo Frankfurte nad Mohanom v júni 1964.

78 Ide o Herberta Abrahama, obávaného vedúceho pracovného nasadenia. Pozri SCHWINDT, Barbara. Das Konzentrations- und Vernichtungslager Majdanek. Funktionswandel im Kontext der ,Endlösung “. Würzburg: Königshausen und Neumann, 2005, s. 233. ISBN 978-3-82603123-6. 
Do tábora Majdanek, pole I som prišiel koncom marca 1942. Horné vrstvy pôdy sa začali topit' a samotný tábor bol postavený uprostred polí a topením snehu sa v celom táborovom areáli nachádzalo bahno až po kolená. Rôzni príslušníci SS, ktorí nás strážili, medzi nimi obzvlášt' raportführer Abraham, zneužívali túto okolnost' a nechávali nás plazit' dookola po štyroch a bili nás bičmi zhotovenými z modlitebných remencov s na konci našitými olovenými gul'ami. Spomínam si na jeden konkrétny prípad.

Bolo to asi v apríli 1942 predpoludním, ked' Abraham vyhnal osadenstvo jedného baraku, všetko starší l'udia, ktorí v ten deň nepracovali na apelplac, rovnako plný bahna. Ja sám som v tú hodinu stál vedl'a obuvníckej dielne, a to vo vzdialenosti cca 50 metrov od apelplacu, a videl som na vlastné oči, ako Abraham v hlbokom bahne nechal starých l'udí robit' „šport“, t. j. museli si líhat' a vstávat' a nemilosrdne ich mlátil bičom. L'udí, ktorí už nedokázali vstat', bil d’alej bičom a svojimi vysokými gumákmi im stúpal po hlavách, až kým sa neponorili do bahna a neudusili sa. Neviem kol'ko l'udí pri tom prišlo o život, nakol'ko som sa nato ukryl. Odhadujem však, že ich bolo asi $10-15$. Neviem, či Abraham bolo jeho skutočné meno, no tak ho volali všetci.

BArch Ludwigsburg, B 162/2349, Bl. 2316-2318. Kópia, strojopis, 3 strany.

Mgr. Ján Hlavinka, PhD.

Historický ústav SAV

Klemensova 19, 81499 Bratislava

e-mail: histjhla@savba.sk

PhDr. Michal Schvarc, PhD.

Historický ústav SAV

Klemensova 19, 81499 Bratislava

e-mail: histmsch@savba.sk 